\title{
The Burdah as a Sufi and Healing Document
}

\author{
Mohammad Saani Ibrahim
}

\begin{abstract}
The author of this article proposes that the Burdah of al-Busiri is a multi-thematic poetical work with multi-functional uses. It is first and foremost a book of eulogies to Prophet Mohammad, extending into panegyric. But it also serves as a source of blessing to Sufi oriented-Muslims, for whom its recitation confers spiritual and physical therapeutic benefits. In addition, the Burdah can be read as a versed historical narrative of the life of the Prophet, although in a highly stylized form. And for others, it serves as a sourcebook of Sufi doctrinal beliefs. The scholar must bear in mind its plural significance when treating the work under any of the above categories, as these intersect at many levels.
\end{abstract}

\section{Introduction}

The Burdah of al-Busiri is generally acknowledged to be the most popular and widespread verse panegyric of the Prophet, as well known in the Middle East and other far-flung corners of the Muslim world as it is in North and West Africa, where it originated. It has also been the subject of a vast number of commentaries: Carl Brockelmann (d. 1956) lists about seventy such in Arabic. The noted historian Abu Shama (d. 655/1268), the reputed theologian al-Bajuri and the celebrated contemporary orientalist scholar Ignaz Goldziher (d. 1921), to mention only a few, have all written about it.

\footnotetext{
Mohammad Saani Ibrahim is an independent scholar based in Montreal. A specialist in Sufism in West and Subsaharan Africa, where he was involved extensively in NGO work as well as the proprietor of Hasaniya school, he holds a Ph.D. from McGill University. His thesis explored the dynamic between Wahhabi and traditional Islam in Ghana and the surrounding region, focusing particularly on the changing role of the Tijaniya Sufi order.
} 
In view of its popularity I will examine some selected lines from the poem which appear to have an affinity to some particular Sufi doctrines. Similarly, several other verses will be selected and analyzed as regards the healing potential they are said to harbor. The first part of this paper will provide a concise yet detailed biography of al-Busiri and an account of his works. The second part will examine selected verses and the Sufi doctrines to which they appear to allude. The last part will look at some other verses and the extent of its healing propensity.

\section{Biography}

Al-Busiri's full name was Muhammad ibn Sa'id ibn Hammad ibn 'Abd Allah al-Sanhaji al-Busiri al-Masri Sharaf ad-Din Abu 'Abd Allah. He was of Moroccan origin, born to the Qal'at Hammad clan (better known as the Bani Habnun) in the village of Bahshim. The name "al-Busiri" is derived from the Banu Suweif of Egypt, from whence his mother hailed. ${ }^{1}$ The year of his birth is variously estimated to have been anywhere from 606/1209 to 608/1211; the same uncertainty surrounds the year of his demise, which is said to have fallen some time between 694/1295 and 697/1297. ${ }^{2}$

Al-Busiri commenced his academic career by memorizing the Qur'an in his native region. He then went to Egypt to study the religious sciences as well as Arabic grammar, syntax, prose, and literature, in addition to the history of Islam, especially the life of the Prophet. He studied all of these subjects at the mosque of Shaykh 'Abd al-Zahir. Later in life he became a disciple of Abu al-'Abbas al-Mursi, the khalif fah of Abu Hassan al-Shadhili, from whom he is said to have studied the Islamic mysticism of the Shadhiliyya order. These studies, it is speculated, may have given rise to the Sufi nature of his magnum opus, the Burdah. ${ }^{3}$

His employment as a court-guardian implies that his knowledge of Islamic jurisprudence must have been sound. He is also said to have been a government official in Bilbis, Egypt. While working in these capacities, he studied books written by Jews and Christians in support of their religion and denying Muhammad's prophethood. This is said to have spurred him to undertake a meticulous study of the Bible and the Torah, alongside that of the history of Christianity's advent. Thereafter, he started writing responses to prove and convince both parties that neither of their scriptures sanctioned the divinity of Jesus, only his prophethood. Furthermore, he maintains that the Bible speaks of the advent of a prophet from the lineage of Isma' $i$ l and vehemently refuted the sins attributed to the prophets in the Torah. ${ }^{4}$ Exposure to these influences could have been a contributory factor in the production of his masterpiece. 


\section{The Burdah}

Muhammad b. Shakir's ${ }^{5}$ Fawat al-Wafayāt quotes al-Busiri as having said that he used to compose poems in praise of the Prophet, some of which he discussed with the companion of Zayn al-Din Ya'qub ibn Zubayr before writing them. Shortly before this, he was struck by a condition of semi-paralysis. During this period, he thought of composing the Burdah, which he then used as a source of intercession with Allah to cure him. He says that after forming the intention, he began reciting it while crying, praying, and seeking intercession. One night he saw the Prophet in his dream passing his blessed hand over his afflicted side and covering him with his mantle or cloak (burdah). When he woke up, he discovered that he had been cured. He quickly left the house without informing anybody. An ascetic met him and asked him for the poem he had recited in the Prophet's presence the previous night. When asked in turn how he knew about the poem, the ascetic answered that he had also been present during its recital. At this point, al-Busiri gave him the poem and news about it spread until it reached Bahauddin b. Hinna', al-Malik az-Zahir Baybars' prime minister, who also asked for it ${ }^{6}$ and, after receiving it, gave it wide publicity. ${ }^{7}$ News of it even reached $\mathrm{Sa}^{\prime} \mathrm{d}$ al-Din, who used it to cure his eye disease.

The content of the burdah consists of 162 lines, with the following subject breakdown: The first 10 lines are of the erotic, spiritual, and symbolic nature of $j \bar{a}$ hili poetry and in this sense resemble an ordinary love poem. The next 16 lines deal with the soul and its passion. The following 30 lines contain mainly praise to the Prophet, while the subsequent 19 talk specifically about his birth. Ten further lines dwell on his supplications, after which 20 lines are devoted to praising the Glorious Qur'an, while the remaining lines consist of invocations. ${ }^{8}$

Al-Busiri is said to have intended to imitate Ka'b ibn Zuhayr, who had produced a composition similarly entitled al-Burdah, because he sought thereby to invoke its blessings. The Burdah of al-Busiri is also called Bara 'at since it was the source of his cure. It is likewise called Qasidat al-Shada 'id, based on the claim that when read it brings release from suffering.

\section{Sufi Doctrines in the Burdah}

Opinion among scholars is divided as to whether the Burdah has any mystical content. René Basset (d. 1924), who translated it, concluded that this poem contained no trace of Sufism. ${ }^{9}$ As a matter of fact, as the poem can be comprehended on a variety of levels, it is hardly surprising that some scholars 
have viewed it from different perspectives. These scholars cannot be far wrong, since the Burdah is poly-thematic in nature. Given this reality, the individual scholar's area of interest will determine in large part the conclusions that he/she draws.

It is hard to attribute the Burdah's alleged Sufi connections to the handiwork of Sufi commentators alone. Although the poem appears to be a plain and down-to-earth account of how traditional Muslims perceive the Prophet's life, yet it is undeniably a repository of Sufi doctrines. Moreover, it is coated with the Shadhiliyya perspective on the Prophet, which al-Busiri acquired from his affiliation with the order. Tentative examples will be given in due course to buttress this point.

Despite the legendary complement that he has acquired over the years, al-Busiri does not seem to figure into biographical literature as a Sufi himself, for instance, as a perfect master (shaykh kämil). ${ }^{10}$ Sha'rani (d. 973/ 1565) does not mention him in his Țabaqāt, nor does an-Nabhani (d. 1350/ 1932) make mention of him in his Jāmi ' Karāmāt al-Awliya $\bar{a} \cdot{ }^{11}$ Even Ibn Ata Allah, the leader of the Shadhiliyya order at that time and number three in the silsilah (chain of Sufi transmission), is said to have referred to him only as an excellent belles-lettrist. ${ }^{12} \mathrm{He}$ did not even employ the word shaykh with reference to him. All this evidence serves to point to al-Busiri's inability to satisfy the conditions of his order fully enough to be endowed with the spiritual title of $s \bar{u} f i$. At best, al-Busiri may have been considered a mutasawwif. It is clear, however, that his poem reveals his stand in this realm of spirituality, which I will demonstrate here by using selected verses as yardsticks.

A thematic study of this work reveals lines that can undoubtedly be said to have Sufi doctrinal connotations. Among the numerous seemingly Sufi doctrines found therein are those of self-mortification or annihilation ( $f a n \bar{a})$; the Muhammadan reality or light (haqīqat al-Muhammadīyah or nūr Muhammadī); and intercession, repentance, reverence, unification, love, abstinence, and trust.

To begin with, the Sufism born in the aftermath of the Mongol's thirteenth-century invasion and wanton destruction on eastern part of the Muslim world had the concept of the Muhammadan reality as its main focal point. In fact, this concept can be said to be the brainchild or formulation of Ibn al'Arabi (d. 1240) that, in conjunction with other doctrines, he might have assimilated from the Neoplatonic influence in vogue at that time. ${ }^{13}$ These doctrines were given practical dimensions by the Sufi orders that sprang up 
after him. His magnum opus, the Futūhāt al-Makkìyah, came to serve as an encyclopedia for Sufis of this era. Victor Danner (d. 1990), in his "Al- Busiri: His Times and His Prophetology," states that Ibn al- "Arabi provided the doctrines while the Sufi orders provided the spiritual methods. ${ }^{14}$ According to Danner, the Prophet's celestial nature, which frequently comes up as a theme in al-Busiri's poem, may be attributed to his birthright. Coming from a purely traditional Islamic background, this idea was always an integral part of his thought. Moreover, his inclination toward a particular Sufi order (al-Shadhiliyya) could have been a factor in lending a Sufi character to this poem. There was also the matter of his own inspiration, given that he was a practicing member of the order as well. ${ }^{15}$

The Sufi doctrine of self-mortification, a process by which initiates are trained to discard their egoistic sensuality, is present in this poem. The adherent is now set on the path to achieve the desired goal of Gnosticism. A typical example can be drawn from the Minhat al-Aṣhāb. In it, Ahmad ibn 'Abd alRahman al-Rutbi states:

It is your duty, my brother, to struggle with the soul, this being the major jihad, to the end that the soul may be delivered from reprehensible attributes through their substitution by praiseworthy ones. ${ }^{16}$

Al- Busiri expresses a similar sentiment in his poem. Manifestations of this Sufi doctrine are scattered throughout its verses. For instance, he cautions against the soul's desires and Satan's deception in verses 17-25. This comes after the poet's admission of his failures due to his own succumbing to his soul's evil leanings. These influences so overpowered him that even he ignored the forewarnings of old age and death, as he states in verses 8-16. Other verses on old age and youth and days wasted in wishful playing and borrowed glory dwell on the same issue. His expertise in expressing his regret for that aspect of his own life, during which he spent lavishly and committed sins and bad deeds (verses 140-44), points to the same theme. Al-Busiri's further warning against hunger and satiety, along with the analogy he draws between the soul and the breast-feeding baby, are all part of the same theme. ${ }^{17}$

The sanctity and fame ascribed to this poem among others of its kind would never have been attained without the belief that it was originally recited in the Prophet's presence. This element has ever since been the preoccupation of later Sufi adherents, who lay great stress on seeing the Prophet while awake or asleep (yaqzah aw manām). Thus, another Sufi characteristic justifies our calling the Burdah a Sufi document. ${ }^{18}$ 
Even the poem's erotic introduction, which is reminiscent of the architecture of jahhili poetry, is spiritual in nature, opening as it does with al-Busiri's expression of passion and yearning for the Prophet, presented symbolically in these verses 1-7. This passion is directed toward the Hijaz and its environs, which witnessed the birth, upbringing and all the stages of the Prophet's life, in both pre and post-prophetic times. In other words, the land of Hijaz, the living witness to those memorable events in the annals of Islam, needs to be shown the proper reverence. ${ }^{19}$ This falls within the Sufi doctrine of venerating the Prophet, as can be seen here:

No perfume can equal the dust on his bones;

Lucky is the one who smells its fragrance and kisses it. (verse 57)

If "dust on his [the Prophet's] bones can be accorded such a high recognition by just scenting or kissing it, then the implication is that the veneration that must be rendered to his personality is immeasurable.

The Sufi doctrine of intercession shows up in verses 155-56. Here alBusiri shows his optimism that all his sins will be forgiven due to the Prophet's intercession. For that matter, the soul should not submit to the defeatist attitude of hopelessness because God's Mercy is so immense that He is able to forgive all of humanity's sins. ${ }^{20}$

The doctrine of trust, which is expressed in Sufi parlance as husn zann fi Allāh, is found in verses $155-57$. It postulates that people should relate to God in such a way that He becomes the all in all for them. Al-Junayd has this to say on trust: "The reality of trust is that a man should be God's in a way he has never been, and that God should be his as he has ever been." ${ }^{21}$ In the poetic language of al-Busiri, this is expressed as follows:

The souls do not despair over the gravity of your faults;

Great sins when forgiveness comes are like small ones.

When God divides His mercy, its shares

Perchance may equal the size of transgression.

Oh lord, let my hope in You not be thwarted,

And not annul my account with You. ${ }^{22}$

The Sufi doctrine of states and illumination has also manifested itself in this legendary production. The theme of $m i$ ' $r \overline{a j}$, in which the Prophet ascended to the heavens and appeared at the pinnacle of a heavenly hierarchy of holy prophets and messengers (see verses 105-17), is invoked. Muhmmad is said to be the only person who has ever received such an honor. Through him, the rank of pre-eminence has been conferred upon the entire Muslim community. ${ }^{23}$ 
At the same time, the Sufis view this singular incident as the rank that they aspire to reach in their bid to achieve knowledge of gnosis ( $m$ a 'rifah). Thus they assert that the Prophet is the perfect model for humanity to emulate. They contend that those Sufis who surmount this state have achieved wușül (union) and fan $\bar{a}^{\prime}$. Thus they do not have to remain in this state but can return to the state of $b a q \bar{a}^{\prime}$ (subsistence) to make themselves accessible to their people. The $m i$ ' $r \bar{a} j$ thus contains a multitude of Sufi doctrines, as envisaged above, all of which strongly suggest that the work is a repository of Sufi teachings and hence merits being described as a Sufi document.

As said above, al-Busiri's Dìwān is not only limited to praising the Prophet. ${ }^{24}$ However, it is nevertheless in the eulogies of the Prophet that we find the poet's prophetological ideas. For example:

The sum of our knowledge about him is that he is human

And that he is the best of God's creation. (verse 51)

Attribute to him whatever honor you wish, Ascribe to his rank any greatness you wish, (verse 44)

Forget all the Christians pretend against their prophets; Devise and decree what you wish in his praise, ${ }^{25}$ (verse 43)

The verses cited above are indicative of al-Busiri's concept of the Prophet at the exoteric level. This fits in well with the ordinary person's view of Muhammad, for it takes in his historical personality and excellent virtues and qualities. The same poem, however, also visualizes the Prophet at the level of esotericism, at which point it addresses itself to Sufis.

Comprehension of his meaning confounds mankind;

All appear dumbstruck, be they distant or near,

Like the sun, which appears small to the eye

From afar, and blinds when viewed from close at hand. (verses 48-49)

In the above verses, the poet expresses the inability of human beings to know the Prophet as befits his status. He then draws an analogy between the sun and the Prophet; thus the Prophet, like the sun, appears to be small to those who do not know him at the esoteric level, whereas those who tread the path view him at close range and so are aware of his magnanimity.

In addition, the notions about the Prophet expressed above refer to his universal nature, which cannot be understood by the ordinary mind. ${ }^{26} \mathrm{Al}$-Busiri concedes this by asking a rhetorical question, 
How in this world can his true nature be grasped?

By a people of sleepers concerned only with dreams? (verse 50)

The reality (haqiqah) is Muhammad's true inner nature, the source of excellence. It is veiled from the ignorant like a secret. This can be better understood against the background of the Wahhabi conception of the Prophet. They are said to look at him as an envelope in which a letter has been put. After having delivered the message, his mission is over - nothing more, nothing less. Therefore, perceiving him beyond this limit transgresses the bounds of the Shari'ah, and hence is an innovation. They subscribe to the notion of the historical Muhammad and refute the idea of his transhistorical nature.

How should his needs draw to the world one without whom

The world would not have been extracted from the void? (verse 33)

And that all noble messengers' miracles before him

Becomes theirs only through his light.

He is the sun of excellence; they are its stars,

Reflecting its rays for people in the dark. (verses 52-53)

Here the Sufi concept of $n \bar{u} r$ Muhammadi is apparent: the spirit of Muhammad is at the center of the universe and was the first thing to be created. His reality is said to have preceded the world. If not for his sake, the world would not have come into existence. The Sufis support their contention with hadiths in which the Prophet is quoted as having said: "I was a prophet when Adam was between water and clay." There is also Jabir ibn "Abd Allah alAnsari's narration: "I asked the Prophet: 'What was the first thing God, the Most High, created?' He replied: 'The light of your Prophet..."' To the Sufis, Muhammad is the solar principle from which other messengers and prophets, as well as the Muslim sages and saints, derive their reflected light. ${ }^{27}$

\section{A Healing Document}

The Burdah's healing aspect has been part of the poem's history from the onset. The biographers of al-Busiri report that the poem was composed during a state of semi-paralysis as brought on by a serious illness. Upon completing it, the poet apparently prayed to God for his recovery. He believed that the Prophet appeared to him in a dream, passed his hands over his forehead, and draped his mantle (burdah) around him. Upon waking up, his paralysis had lessened and he got up and walked. This story spread like wildfire and en- 
hanced the poem's fame. Miraculous powers have been ascribed to it ever since. ${ }^{28}$

Although the poem makes no specific mention of al-Busiri's physical illness, it certainly harbors evidence of a spiritual crisis. At is beginning, the poet is in a state of despair, which explains his expression of bitter remorse over his moral failures. Through imitating and praising the example of the Prophet, he acquires some confidence and, at the end of the poem, expresses the conviction that his sins are worthy of forgiveness. This therapeutic element, inherent in the poem's very structure, gave the Burdah its reputation of being a healing document. ${ }^{29}$

How many sick he [the Prophet] cured with his palm,

How many afflicted he freed from madness' chains!

How often his call has restored such life to the ashen year of drought

That its abundance out shone the seasons of plenty,

With clouds so generous the valleys seemed as though

Submerged by the sea or drowned in the flood of Dams. (verses 85-88)

The poet, in recounting the Prophet's healing ability, sounds as though he is trying to invoke these very same powers. He cites specific instances, such as when the Prophet is said to have extended his hand to a ewe that was devoid of milk and it produced milk - a miracle tht apparently led to Ibn Mas'ud's conversion. Muhammad is also said to have cured Ali, his son-in-law, of an eye affliction on the Day of Khaybar by means of his saliva. Furthermore, it is said that when a serious illness rendered Jabir ibn 'Abd Allah unconscious, the Prophet healed him by sprinkling water over him. ${ }^{30}$ During al-Busiri's lifetime, Ibn Hinna handed a written form of the ode to al-Muwaqqi (d. 1291), a poet and high official who suffered from partial blindness. Immediately after he put it over his eyes he was cured. Thus, the Burdah's healing power was perceived to have its source in the Prophet. ${ }^{31}$

Even one of the names given to the poem - Al-Bur' $a$ (The Healing) alludes to its healing potency. This particular characteristic is believed to be derived from the grace enclosed within its verses and generated during its recitation, which "heals" the person who has faith in it of his/her physical, mental, or other type of illness. ${ }^{32}$

The poems of Ibn al-Farid (d. 1234) and al-Shushtari (d. 1269), for example, are known throughout the Arabian Peninsula and the entire Arab world and are recited constantly. All the same, neither they nor any other poems not even Ibn al-Farid's Khamriyah - contains the talismanic, theurgical, and even magical properties associated with the Burdah's recitation. ${ }^{33}$ 
Attached to the Burdah are all sorts of supernatural qualities. For that matter, it has been used on religious occasions ranging from celebrating the Prophet's birthday (mawlid al-nabi) to funerals. In fact, its recitation has to be preceded by the ritual of ablution, just like in prayer. Furthermore, those who recite it have to do so while facing the Ka'bah. All such conditions give the work a kind of extra-canonical ritual importance that elevates it infinitely beyond the recitation of profane poetry. ${ }^{34}$

In his commentary on this work, al-Bajuri draws attention to some of the verses' healing or spiritual functions. A few will be cited here as examples.

Yes, I admit my beloved's apparition has robbed me of my sleep.

Love will spoil all pleasure with pain. (verse 8)

Al-Bajuri indicates that if this particular verse is recited after the late evening prayer ( $i s h \bar{a}$ ) until one falls asleep, that person is assured of seeing the Prophet in his/her dream by the grace of God..$^{35}$

You advice is most sincere but what you say I cannot hear.

To the riling of his critics the lover is stone dead.

Even the advice of age I spurned when it censured me.

Yet age is far above suspicion in its counsel. (verses 11-12)

These two verses are said to be love potions, but should be used to charm a lover with whom one intends to enter into wedlock. It is stated that if one falls in love with a woman but feels shy about approaching her, reciting these verses will ensure that he will have the woman to himself. ${ }^{36}$

And drain off tears an eye once filled

With forbidden sights, and stick to the diet of remorse.

Oppose the Self and Satan and rise up against them;

Treat their claim of good counsel with mistrust. (verses 24-25)

These verses are said to be a cure for those who have strong or hardened hearts. In such cases they have no power over themselves; rather, they are being controlled by their negative ego. From al-Bajuri's commentary we learn that if these two verses are recited on Friday at the time of sahr (dawn), by the morning of that day he/she will be cured of this affliction. The result is a feeling of softness in the heart, readiness of body's parts to embark on worship, and a feeling of regret for past misdeeds. ${ }^{37}$

From the above-cited verses and the various healing functions that they are said topossess, it is clear that the Burdah owes as much of its popularity to its perceived role as a healing document as it does to its evocation of the Prophet's life or its sufi character. 


\section{Conclusion}

The fact that the Burdah as a whole covers so many themes makes it very difficult to arrive at a common conclusion acceptable to all. Indeed, any scholar who studies it usually comes up with his/her own conclusion. It is, therefore, not surprising that Basset should have concluded that it was "almost exempt from the traces of Sufism," whereas Danner remarked that the Burdah contains Sufi doctrines but so discreetly as to go almost unnoticed. ${ }^{38}$ Based on my own observations, however, it is not unreasonable to see the work as both a Sufi and a healing document.

\section{Endnotes}

1. 'Ali Najib 'Atawi, Al-Būșīrī, Shā’ir al-Madā'iḥ al-Nabawīyah wa-'Alamuhā, ed. 'Ali Najib 'Arawi (Beirut: Dar al-Kutub al-'Ilmiyah, 1995), 79.

2. Victor Danner, "Ibn 'Ata'Allah: A Sufi of Mamluk Egypt: An Introductory Study of the Origins of Shadhiliyya and Translation of Kitab al-Hikam," thesis, 1970.

3. 'Atawi, Al-Busiri, 80.

4. Ibid., 82 .

5. Muhammad ibn Shakir, Fawāt al-Wafayāt (Cairo: Maktabat al-Nahdat al-Arabiyat al-Misriyya, 1951), 481.

6. Ibid., 481.

7. Danner, "Ibn 'Ata'Allah," 106.

8. 'Atawi, Al-Būṣìrī, 121.

9. C. D. Bosworth, "Al-Busiri, Sharaf al-Din," in The Encyclopaedia of Islam, 2d ed. (Leiden: E. J. Brill, 1980; Supplement 1987), 158-59.

10. Danner, Ibn 'Ata'Allah, 129.

11. Sha'arani, Jāmi ' Karāmāt Awliyā', 2 vols. (Cairo, 1381/1962).

12. Ibn 'Ata'Allāh, La sagesse des maîtres soufis, trans. Eric Geoffroy (Paris: Grasset, 1998), 260.

13. Victor Danner, "Al- Busiri: His Times and Prophetology," in Islamic and Middle Eastern Societies: A Festschrift in Honor of Wadie Jwaideh, ed. Robert Olson and Salman al-Ani (Brattleboro, VT: Amana, 1987), 42.

14. Ibid., 43.

15. Ibid., 41.

16. J. S. Trimingham, The Sufi Orders in Islam (New York: Oxford University Press, 1998), 155.

17. Stefan Sperl and Christopher Shackle, eds., Qasida Poetry in Islamic Asia and Africa (Leiden and New York: E. J. Brill, 1996), 2:471.

18. Sa'id ibn al-Ahras, Burdat al-Būșìrī bi al-Maghrib wa al-Andalus khilāl al-Qarnayn al-Thāmin wa al-Tāsi ‘ al-Hijrīyayn (Morocco: Wizarat al-Awqaf wa alShu'un al-Islamiyah, 1998), 539. 
19. Ibid., 538 .

20. I rely upon Sperl's translation of the Burdah.

21. A. J. Arberry, trans., The Doctrine of Sufis, 2d improved ed. (New Delhi: Kitab Bhavan, 1994), 89. Translation of Abū Bakr al-Kalābādhī's Kitāb al-Ta 'arruf li Madhhab Ahl al-Tașawwuf.

22. Sperl and Christopher, Qasida Poetry.

23. Ibid., 472.

24. Ibid.

25. Danner, "Al-Busiri," 52.

26. Ibid.

27. Ibid., 54.

28. Ibid., 51.

29. Ibid.

30. D. A. DeWeese, The Kashf al-Huda of Kamal ad-Din Husayn Khorezmi: A Fifteenth-century Sufi Commentary on the Qasidat al-Burdah in Khorezmian Turkic (Ann Arbor, MI: U.M.I. Dissertation Service, 1985), 365.

31. Ibid.

32. Danner, "Al-Busiri," 50.

33. Ibid., 51.

34. Ibid., 50.

35. Ibrahim ibn Muhammad al-Bajuri, Hāshīyat Ibrāhīm al-Bājūrī 'alā Matn alBurdah (Bombay: Abna' Mawlawi, 1982), 9.

36. Ibid., 11.

37. Ibid., 18.

38. Danner, "Al- Busiri," 50. 